\title{
A COMPARISON OF RADIOCARBON AND U/Th AGES ON CONTINENTAL CARBONATES
}

\section{J.-C. FONTES, J. N. ANDREWS ${ }^{1}$, CHRISTIANE CAUSSE and ELISABETH GIBERT}

Laboratoire d'Hydrologie et de Géochimie Isotopique, Bâtiment 504, Université de Paris-Sud 91405 Orsay Cedex, France

\begin{abstract}
Authigenic micrite from a playa in the northern Sahara has been dated by both the U/Th and ${ }^{14} \mathrm{C}$ methods. The U/Th ages can be a few thousand years greater or less than the ${ }^{14} \mathrm{C}$ ages obtained on the smallest crystals of micrite. The latter are considered to form a reasonable chronology for the Holocene deposits. The deviations of the U/Th ages are explained by quantifiable losses and gains of uranium under changing redox conditions. Under conditions where $U$ is conservative (reduced sediments with low permeability), the U/Th method can provide good chronologies for lacustrine deposits.
\end{abstract}

\section{INTRODUCTION}

Recent developments in paleoclimatic and paleohydrologic studies of continental deposits (Talbot \& Kelts 1986; Hillaire-Marcel \& Casanova 1987; Gasse et al. 1987, 1990) have drawn new attention to the validity of ${ }^{14} \mathrm{C}$ ages in lacustrine sediments. Whereas dating of marine sediments is mainly concerned with the problem of bioturbation, ${ }^{14} \mathrm{C}$ chronologies on lacustrine deposits must address the question of the origin of the total dissolved inorganic carbon (TDIC) in lake waters. Three main sources of TDIC can be distinguished (Fontes \& Gasse 1991): 1) recent atmospheric $\mathrm{CO}_{2} ; 2$ ) old carbon from large aquifers where radioactive decay has occurred, or from dissolution of fossil carbonates; 3$) \mathrm{CO}_{2}$ of deep origin that may be released along fault systems. The problem for ${ }^{14} \mathrm{C}$ dating in paleolakes is the same as that for groundwater dating, with the additional complication of possible re-equilibration of the TDIC with atmospheric $\mathrm{CO}_{2}$. Such uncertainties for ${ }^{14} \mathrm{C}$ dating of paleolake material apply to carbonates as well as to organic matter of aquatic plant origin, which derives its carbon from TDIC rather than from atmospheric $\mathrm{CO}_{2}$. Living aquatic plants and the flesh of related grazing gastropods have shown apparent ages of $13 \mathrm{ka}$ in the Wadi el Akarit system of southern Tunisia, which is supplied by an old aquifer (Zouari 1987). The ${ }^{13} \mathrm{C}$ content cannot provide unquestionable evidence for a recent atmospheric origin. This is because of the large isotopic difference between $\mathrm{CO}_{2}$ that passed through the aquatic vegetation cycle $\left(\delta^{13} \mathrm{C}\right.$ $\sim 20 \%$ vs. PDB, Deines 1980) and $\mathrm{CO}_{2}$ that dissolved directly from the atmosphere $\left(\delta^{13} \mathrm{C} \sim 7 \%\right.$ vs. PDB). Consequently, the validity of ${ }^{14} \mathrm{C}$ ages for lacustrine sediments has to be assessed on the following criteria: 1) authigeny of carbonate crystals inferred from scanning electron microscopy; 2) the fit of apparent ages into the stratigraphic sequence; 3 ) agreement between ${ }^{14} \mathrm{C}$ ages derived from coeval organic matter and carbonates; 4) the confirmation that modern sediments yield recent ages. However, as paleohydrologic conditions have changed in the past, these criteria are of relative value, and direct comparison of apparent ${ }^{14} \mathrm{C}$ ages with other independent chronometers is needed.

Comparison can be made with varve or laminae counting in favorable conditions, e.g., Lake Gosciacz (Rozanski et al. 1992) or by U/Th measurements. Bard et al. (1990) have made extensive comparisons of $\mathrm{U} / \mathrm{Th}$ and ${ }^{14} \mathrm{C}$ ages in the marine environment, where closed-system conditions prevail for fossil aragonite corals recovered from submarine cores. In such closed conditions, the concentration of $\mathrm{U}$ and $\mathrm{Th}$ in the solid phase can change only by radioactive decay and ingrowth. Closed-system conditions may not exist for lacustrine deposits that could have been affected by

${ }^{1}$ Postgraduate Research Institute for Sedimentology, University of Reading, Whiteknights, Reading RG6 2AB, UK 
groundwater circulation under various redox conditions, and therefore, under changing regimes of $\mathrm{U}$ mobility. Consequently, few direct comparisons of ${ }^{14} \mathrm{C}$ and U/Th data are available for continental deposits (Kaufman \& Broecker 1965). One such study, of great paleohydrological interest, showed that lacustrine deposits in the Sahara, previously ${ }^{14} \mathrm{C}$ dated at $25-35 \mathrm{ka} \mathrm{BP}$, are probably much older (Causse et al. 1988, 1989). We describe below such a comparative study for the Holocene deposits of the Ouargla region (Algeria, northern Sahara).

\section{HYDROGEOLOGICAL SETTING}

The Sebkha Mellala (Fig. 1) is an internal drainage basin (playa) located in a vertical discharge zone of a major Saharan aquifer, the "Continental Intercalaire." This site was selected for detailed paleohydrological reconstruction of the Palhydaf ("Palaeohydrology in Africa") program (Fontes \& Gasse 1991) because of its location in a zone that may have been influenced by precipitation with both northern and southern origins. Because the aquifer is confined, climatic changes in the extent of recharge on the Mzab Heights (Fig. 1) would be reflected by almost contemporaneous changes in the water level of the basin.

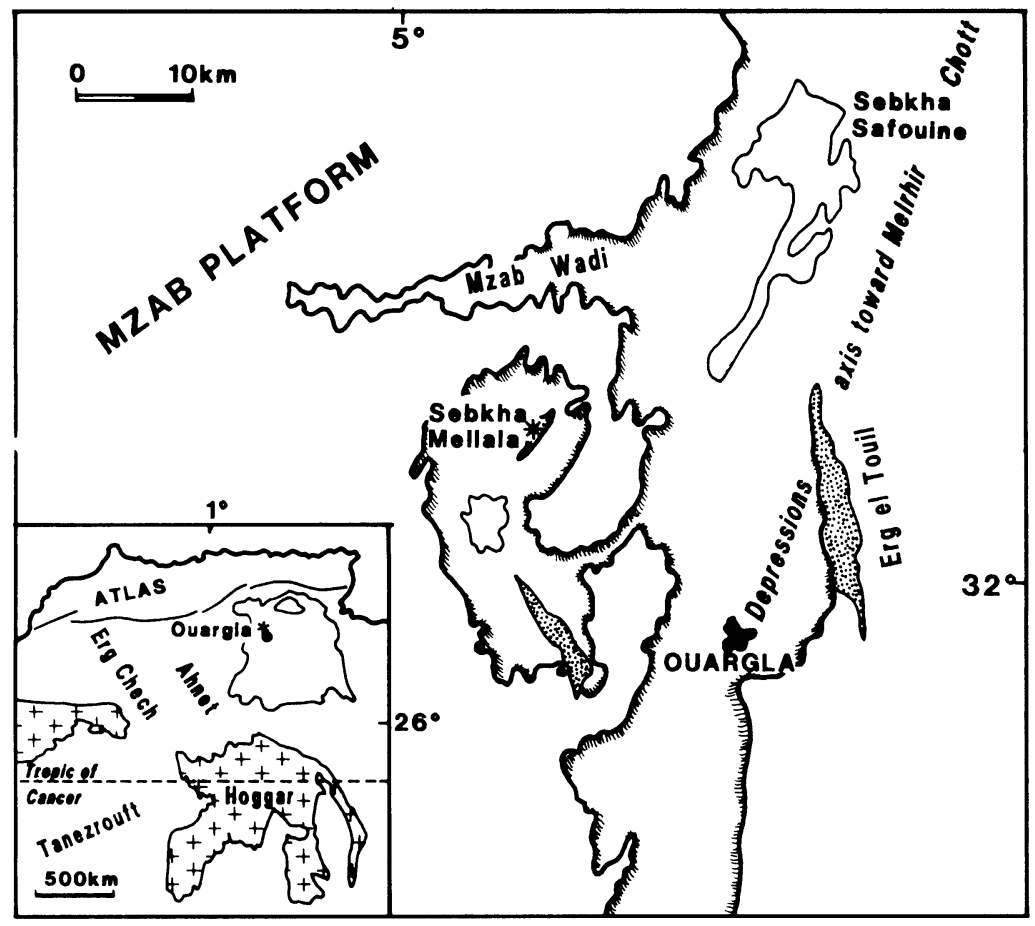

Fig. 1. Location of the Sebkha Mellala, northwest of Ouargla (N. Sahara)

A vertical profile through the lacustrine sediments was obtained from the outcropping of a hummock (formed by eolian erosion), and was extended by hand-auger sampling of sediments below its base (Fig. 2). The ${ }^{14} \mathrm{C}$ chronology was based upon the analysis of small (a few $\mathrm{mm}$ ) idiomorphic crystals of calcimicrite, which crystallized at the lake surface, and therefore reflect close-to-equilibrium conditions with atmospheric $\mathrm{CO}_{2}$. The validity of the ${ }^{14} \mathrm{C}$ time scale for the micrite is supported by the linear relation between age and depth (Fig. 3). A detailed record of climatic fluctuations in this region between 15 and $5 \mathrm{ka} \mathrm{BP}$, including clear evidence for a severe 

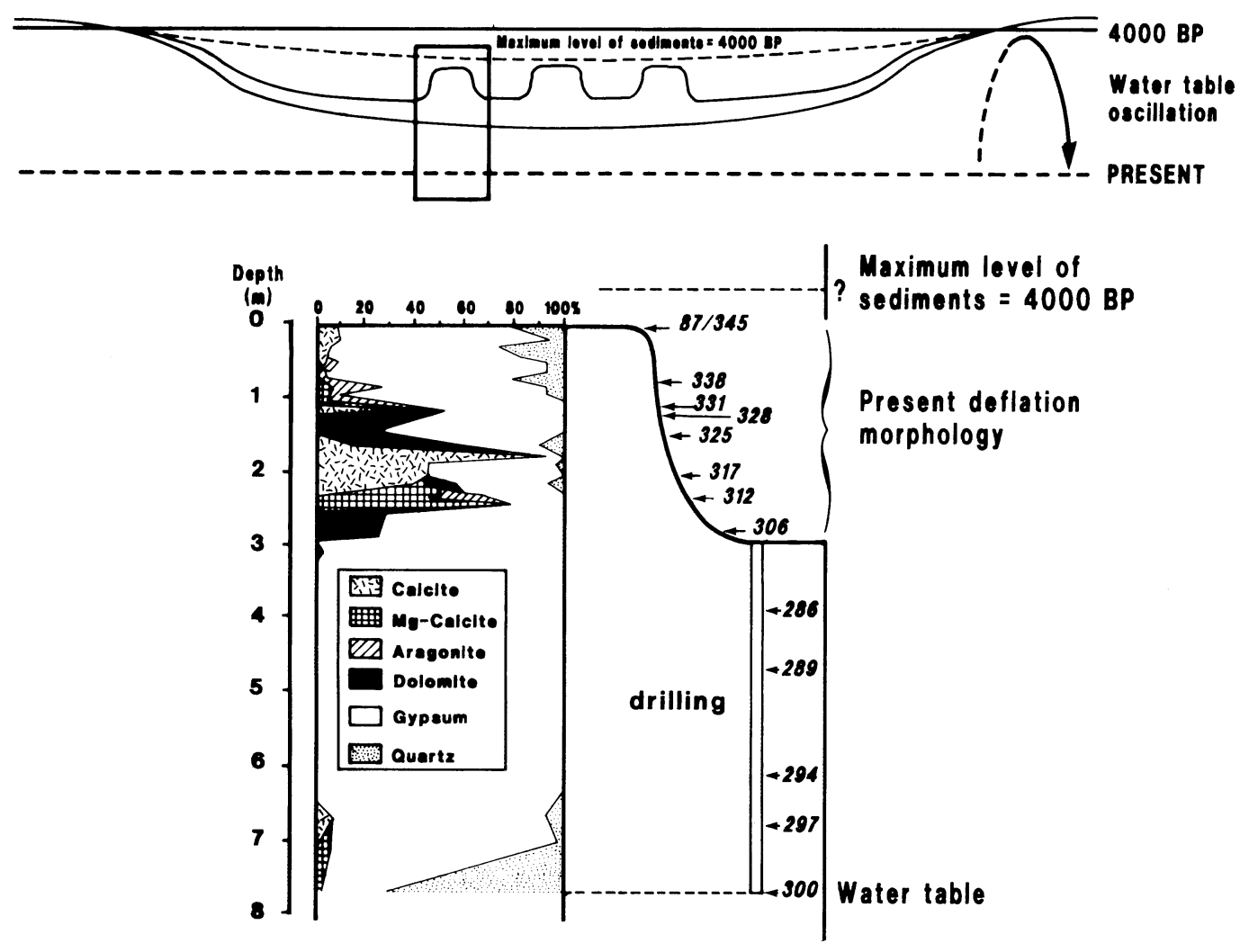

Fig. 2. A. Formation of hummocks by eolian erosion of the Sebkha. B. A section of the studied profile showing the mineralogy and sample locations (Gibert et al. 1990).

dry episode contemporaneous with the Younger Dryas event, was obtained from the stable isotope content of the authigenic calcite (Gibert et al. 1990; Gasse et al. 1990).

However, a large discrepancy was observed between the apparent ${ }^{14} \mathrm{C}$ ages of the micrite and mollusk shells (Cerastoderma). The latter appeared older by about $2 \mathrm{ka}$ (see Table 1), although they were well preserved (connected valves) and not suspected of being reworked. The age difference was attributed to the influence of old TDIC from the confined aquifer in the bottom mud of the basin that forms the mollusk habitat. The U/Th disequilibrium in the shell aragonite was measured in an attempt to confirm the micrite ${ }^{14} \mathrm{C}$ age for the sedimentation. It was expected that the U/Th system would not be influenced by the TDIC, which had caused the discrepancy between the micrite and shell samples.

\section{METHODS AND RESULTS}

For each stratigraphic position, the sediment size fraction $\leq 80 \mathrm{~mm}$ or $\leq 40 \mathrm{~mm}$, in order to concentrate the smallest crystals, was analyzed for both ${ }^{14} \mathrm{C}$ and $\mathrm{U} / \mathrm{Th}$ (Table 1). New and previously published (Gibert et al. 1990) results of both liquid scintillation and accelerator mass spectrometry (AMS) ${ }^{14} \mathrm{C}$ analyses are included in Table 1.

For the $\mathrm{Th} / \mathrm{U}$ analyses, the shells were totally dissolved in hydrochloric acid. For the sediments, the carbonate fraction contained gypsum and detrital material (mainly quartz) of eolian origin, and we therefore applied the method of fractional leachates (Rosholt 1976; Ku \& Liang 1984; Schwarcz 
TABLE $1 .{ }^{14} \mathrm{C}$ and U/Th Data for Late Quaternary Deposits of Sebkha Mellala, Algeria

\begin{tabular}{|c|c|c|c|c|c|c|c|c|}
\hline Sample & $\begin{array}{l}\text { Depth } \\
\text { (m) }\end{array}$ & $\begin{array}{c}{ }^{14} \mathrm{C} \text { Age } \\
\text { ka BP }\end{array}$ & $\begin{array}{l}{ }^{238} \mathrm{U} \\
\mathrm{ppm} \\
\end{array}$ & $\begin{array}{r}{ }^{232} \mathrm{Th} \\
\mathrm{ppm} \\
\end{array}$ & $\begin{array}{r}{ }^{234} \mathrm{U} / 238 \mathrm{U} \\
\text { activit }\end{array}$ & $\begin{array}{l}{ }^{230} \mathrm{Th} / 234 \mathrm{U} \\
\text { y ratios }\end{array}$ & $\begin{array}{c}\text { Age } A_{0} \\
\text { ka }\end{array}$ & $\begin{array}{c}\text { Age } A_{1} \\
\text { ka }\end{array}$ \\
\hline $87 / 345 \mathrm{~A}$ & & & 71.99 & 1.34 & 1.51 & 0.028 & 3.1 & \\
\hline $87 / 345 \mathrm{~F}$ & & & 1.45 & 1.92 & 1.37 & 0.626 & 100.7 & \\
\hline $87 / 345 \mathrm{~W}$ & 0.00 & 4.95 & 12.62 & 1.81 & 1.49 & 0.081 & 9.2 & 5.7 \\
\hline $87 / 345 \mathrm{~T}$ & & & 15.74 & 1.42 & 1.39 & 0.065 & 7.2 & 4.9 \\
\hline $87 / 338 \mathrm{~A}$ & & & 35.36 & 0.43 & 1.53 & 0.020 & 2.2 & \\
\hline $87 / 338 \mathrm{~F}$ & & & 0.96 & 1.22 & 1.44 & 0.902 & 199.7 & \\
\hline $87 / 338 \mathrm{~W}$ & 0.80 & 7.16 & 10.09 & 1.00 & 1.52 & 0.079 & 8.9 & 6.5 \\
\hline $87 / 338 \mathrm{C}$ & 0.80 & $* 8.85$ & 1.07 & 0.00 & 1.56 & 0.117 & 13.4 & 13.4 \\
\hline $87 / 331 \mathrm{~A}$ & & & 39.64 & 0.60 & 1.54 & 0.024 & 2.7 & \\
\hline $87 / 331 \mathrm{~F}$ & & & 1.87 & 2.03 & 1.46 & 0.769 & 142.0 & \\
\hline $87 / 331 \mathrm{~W}$ & 1.15 & ${ }^{*} 7.89$ & 13.57 & 1.57 & 1.53 & 0.092 & 10.5 & 7.7 \\
\hline $87 / 331 \mathrm{C}$ & 1.15 & ${ }^{*} 9.37 / * 9.49$ & 0.80 & 0.01 & 1.42 & 0.093 & 10.6 & 10.2 \\
\hline $87 / 328 \mathrm{~A}$ & & & 31.98 & 0.67 & 1.53 & 0.035 & 3.8 & \\
\hline $87 / 328 \mathrm{~F}$ & & & 0.25 & 0.57 & 1.25 & 2.371 & n. d. & \\
\hline $87 / 328 \mathrm{~W}$ & 1.25 & ${ }^{*} 8.85$ & 5.52 & 0.57 & 1.52 & 0.106 & 12.2 & 9.4 \\
\hline $87 / 325 \mathrm{~A}$ & & & 48.54 & 0.70 & 1.54 & 0.032 & 3.5 & \\
\hline $87 / 325 \mathrm{H}$ & & & 0.45 & 0.46 & 1.53 & 1.330 & n. d. & \\
\hline $87 / 325 \mathrm{~F}$ & & & 0.13 & 0.27 & 1.13 & 2.264 & n. d. & \\
\hline $87 / 325 \mathrm{~W}$ & 1.50 & (9.06) & 7.97 & 0.38 & 1.54 & 0.066 & 7.5 & 6.3 \\
\hline $87 / 317 \mathrm{~A}$ & & & 48.08 & 0.29 & 1.55 & 0.028 & 3.1 & \\
\hline $87 / 317 \mathrm{~F}$ & & & 0.99 & 0.20 & 1.55 & 0.605 & 94.1 & \\
\hline $87 / 317 \mathrm{~W}$ & 2.05 & ${ }^{*} 10.21$ & 10.98 & 0.21 & 1.55 & 0.069 & 7.8 & 7.3 \\
\hline $87 / 312 \mathrm{~A}$ & & & 44.39 & 0.22 & 1.61 & 0.020 & 2.2 & \\
\hline $87 / 312 \mathrm{H}$ & & & 7.85 & 0.22 & 1.52 & 0.143 & 16.6 & \\
\hline $87 / 312 \mathrm{~F}$ & & & 0.17 & 0.16 & 1.44 & 4.459 & n. d. & \\
\hline $87 / 312 \mathrm{~W}$ & 2.35 & ${ }^{*} 10.66$ & 12.40 & 0.19 & 1.59 & 0.069 & 7.8 & 7.4 \\
\hline $87 / 312 \mathrm{~T}$ & & & 9.43 & 0.24 & 1.52 & 0.076 & 8.6 & 7.0 \\
\hline $87 / 306 \mathrm{~A}$ & & & 59.29 & 0.15 & 1.51 & 0.003 & 0.3 & \\
\hline $87 / 306 \mathrm{~F}$ & & & 16.78 & 0.46 & 1.58 & 0.160 & 18.7 & \\
\hline $87 / 306 \mathrm{~W}$ & 2.80 & 10.64 & 32.12 & 0.34 & 1.53 & 0.057 & 6.3 & 6.1 \\
\hline $87 / 286 \mathrm{~T}$ & 3.90 & 11.47 & 11.15 & 1.23 & 1.54 & 0.119 & 13.7 & 11.2 \\
\hline $87 / 289$ A & & & 62.55 & 0.22 & 1.55 & 0.010 & 1.1 & \\
\hline $87 / 289 \mathrm{~F}$ & & & 4.69 & 0.92 & 1.55 & 0.344 & 44.7 & \\
\hline $87 / 289 \mathrm{~W}$ & 4.70 & ${ }^{*} 12.46$ & 19.50 & 0.73 & 1.55 & 0.070 & 7.8 & 7.0 \\
\hline $87 / 289 \mathrm{~T}$ & & & 19.47 & 1.10 & 1.52 & 0.074 & 8.4 & 7.0 \\
\hline $87 / 294 \mathrm{~T}$ & 6.10 & ${ }^{*} 12.95$ & 15.44 & 1.40 & 1.53 & 0.092 & 10.5 & 8.4 \\
\hline $87 / 297 \mathrm{~A}$ & & & 47.39 & 0.23 & 1.54 & 0.018 & 2.0 & \\
\hline $87 / 297 \mathrm{~F}$ & & & 19.72 & 0.64 & 1.44 & 0.162 & 19.1 & \\
\hline $87 / 297 \mathrm{~W}$ & 6.80 & 13.91 & 23.87 & 0.57 & 1.47 & 0.117 & 13.4 & 12.8 \\
\hline $87 / 300 \mathrm{~T}$ & 7.70 & (14.56) & 7.25 & 2.13 & 1.50 & 0.178 & 21.0 & 14.0 \\
\hline
\end{tabular}

A, leached with acetic acid $(\mathrm{pH}=2-2.5) ; \mathrm{H}$, with $\mathrm{HCl} 6 \mathrm{~N} ; \mathrm{F}$, totally dissolved with $\mathrm{HF}+\mathrm{HClO}_{4} ; \mathrm{W}$, reconstructed whole sample; $\mathrm{T}$, total sample dissolved with $\mathrm{HF}_{+} \mathrm{HClO}_{4} ; \mathrm{C}$, Cerastoderma shells totally dissolved in $\mathrm{HCl}$. $A_{0}=$ uncorrected age; $A_{1}=$ corrected age for ${ }^{230} \mathrm{Th}_{\text {excess }}{ }^{232} \mathrm{Th}$ AR values $=1$.

${ }^{*}{ }^{14} \mathrm{C}$ data by AMS; ${ }^{14} \mathrm{C}$ age in brackets is interpolated. 


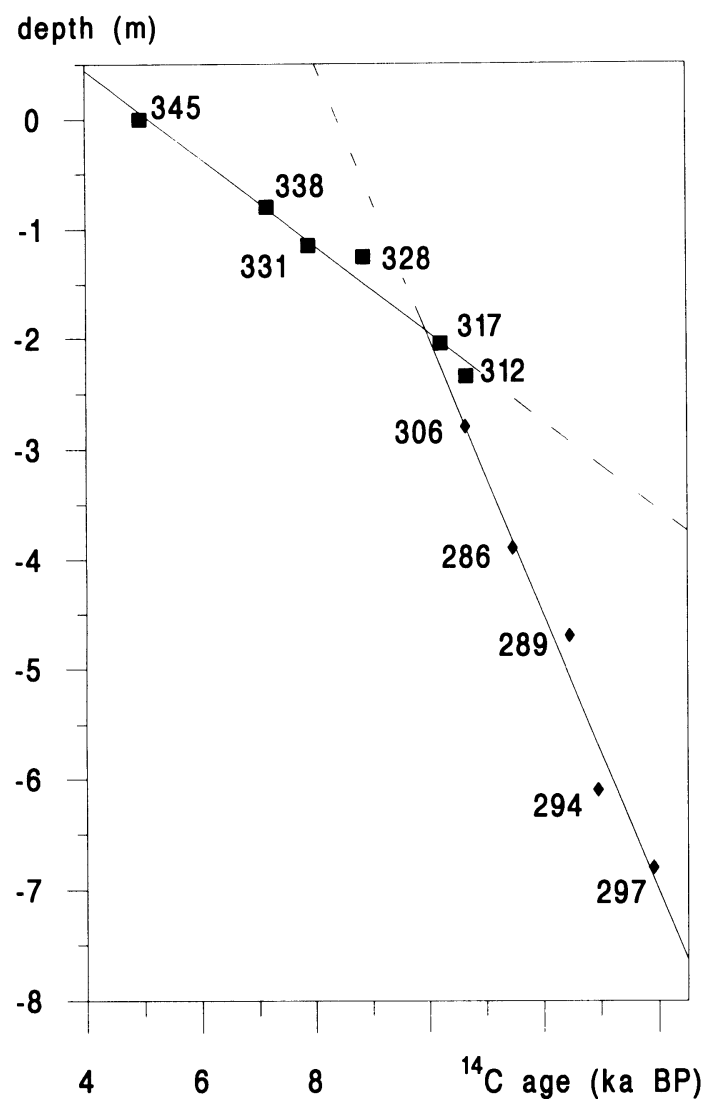

Fig. 3. Radiocarbon ages vs. depth correlation for small crystals of calcimicrite. The sedimentation rate is $0.25 \mathrm{~m}$ $\mathrm{ka}^{-1}$ for carbonate dominated sediments ( $\bullet$ ), compared with $1.25 \mathrm{~m} \mathrm{ka}^{-1}$ for gypsum dominated sediments $(\bullet)$. The lower sedimentation rate corresponds to the last lacustrine episode (4-10 ka BP), for which the catchment supply was more significant. The gypsum-dominated sedimentation prior to $10 \mathrm{ka}$ BP corresponds to more arid conditions.

\& Latham 1989; Przybylowicz, Schwarcz \& Latham 1991) to determine the apparent U/Th age of the carbonate fraction. According to these authors, the influence of the detrital component may be evaluated in a diagram of the $\left({ }^{30} \mathrm{Th} /{ }^{232} \mathrm{Th}\right)$ and $\left({ }^{234} \mathrm{U} /{ }^{32} \mathrm{Th}\right.$ ) activity ratios (ARs) for the partial leachates. The slope of the mixing line is a function of the age of the neogenetic phase if neither gain nor loss of $U$ occurred (closed-system conditions). The samples were first partially leached with acetic acid, and the solid residue was then totally dissolved by a mixture of perchloric-hydrofluoric acids. For samples $87 / 325$ and $87 / 312$, an intermediate leach with hydrochloric acid was also performed, and the residue of the sample was entirely dissolved in perchloric-hydrofluoric acid mixture (Table 1). U/Th dates were determined by $\alpha$-spectrometry. Plots of $\left({ }^{230} \mathrm{Th} /{ }^{232} \mathrm{Th}\right) \mathrm{AR}$ $v$ s. $\left({ }^{234} \mathrm{U} /{ }^{232} \mathrm{Th}\right) \mathrm{AR}$ showed a negative trend (Fig. 4), suggesting that either ${ }^{230} \mathrm{Th}$ adsorption or preferential leaching of uranium had occurred. However, the initial sample and the dried residue were weighed so that mass balance calculations could be used to reconstruct $U$ and Th concentrations and the AR values, $\left({ }^{234} \mathrm{U} /{ }^{238} \mathrm{U}\right)$ and $\left({ }^{230} \mathrm{Th} /{ }^{234} \mathrm{U}\right)$, for the whole sample. Together with a separate totally dissolved sample, this reconstructed value was used to construct an isochron (Fig. 4), which yields an age of $6.6 \mathrm{ka}$, according to the procedure of Bischoff and Fitzpatrick (1991) and Luo and $\mathrm{Ku}$ (1991).

The occurrence of ${ }^{232} \mathrm{Th}$ in the recovered ${ }^{230} \mathrm{Th}$ can be due only to the presence of detritus in the sample. In that case, some ${ }^{230} \mathrm{Th}$ from the particulate supply has been added to that formed by ${ }^{234} \mathrm{U}$ decay in the carbonate. The amount of the detrital ${ }^{230} \mathrm{Th}$ was estimated on the basis that the $\left({ }^{230} \mathrm{Th} /{ }^{32} \mathrm{Th}\right) \mathrm{AR}$ was one, corresponding to the average crustal $\mathrm{U} / \mathrm{Th}$ mass ratio of about three. The 


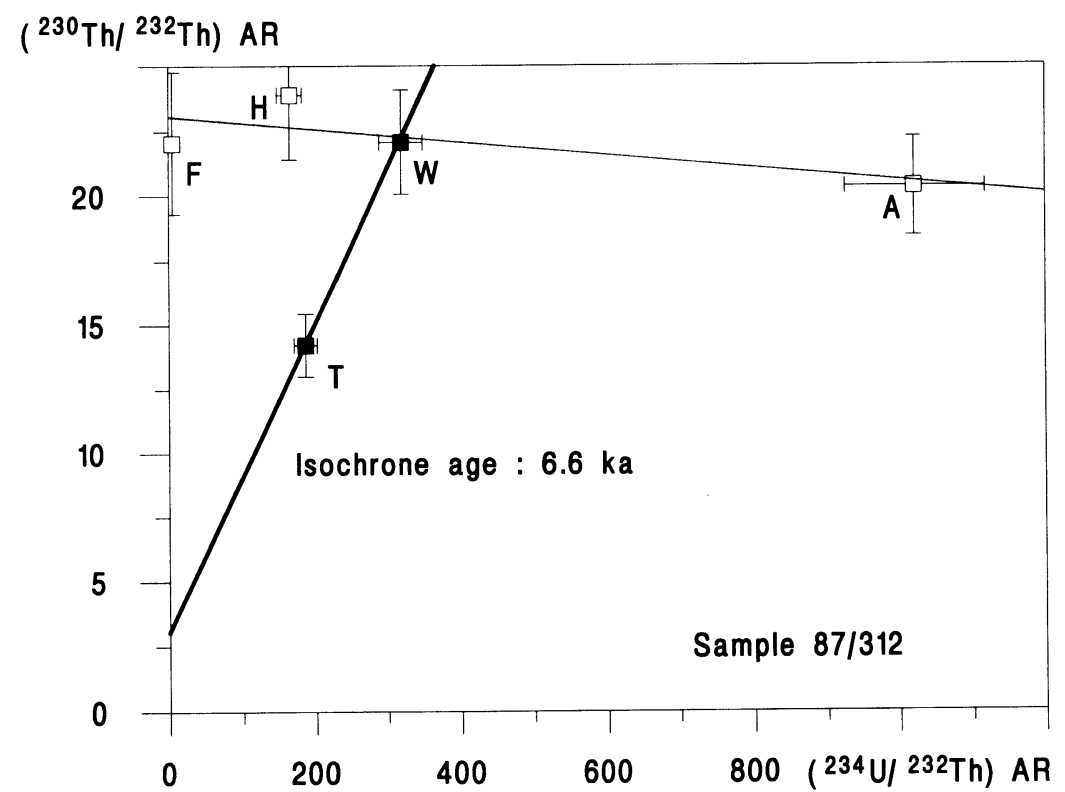

Fig. 4. $\left({ }^{230} \mathrm{Th} /{ }^{232} \mathrm{Th}\right)$ AR vs. $\left({ }^{234} \mathrm{U} /{ }^{232} \mathrm{Th}\right)$ AR correlation diagram for Sample $87 / 312$. A - acetic acid leachate; $\mathrm{H}-\mathrm{HCl}$ leachate; F - totally dissolved residue; W - for the whole sample reconstructed from leachate data; $\mathrm{T}$ - a separate sample, totally dissolved.

corrected ages are given in the last column of Table 1. For the Cerastoderma shells, the detrital Th contamination was very small and age corrections are insignificant.

The corrected U/Th ages for samples well above the level of the Sebkha surface $(0-1.25 \mathrm{~m})$ are in stratigraphic sequence and in reasonable agreement with the corresponding ${ }^{14} \mathrm{C}$ ages on the micrite. However, both the micrite $\mathrm{U} / \mathrm{Th}$ and ${ }^{14} \mathrm{C}$ ages are younger than the corresponding ages on Cerastoderma shells. In contrast, most samples from the middle of the hummock to below the Sebkha surface, but above the water table (1.5-6.1 m), have corrected U/Th ages that are not in stratigraphic sequence and are younger than the corresponding ${ }^{14} \mathrm{C}$ ages. The corrected $\mathrm{U} / \mathrm{Th}$ and ${ }^{14} \mathrm{C}$ ages are in agreement for the lowermost samples (below $6.1 \mathrm{~m}$ ), which were situated close to the present water table. Thus, although reasonable agreement exists between $\mathrm{U} / \mathrm{Th}$ and ${ }^{14} \mathrm{C}$ ages for samples from the upper part of the hammock and for samples from close to the Sebkha water table, the U/Th ages for most samples from the unsaturated zone below the Sebkha surface are younger than the corresponding ${ }^{14} \mathrm{C}$ ages. It is clear that the U/Th system has not remained closed throughout the stratigraphic sequence.

\section{Discussion}

Three hydrological regimes can be distinguished in the studied profile. The sediments of the upper part of the hummock $(0-1.25 \mathrm{~m})$ are subject only to direct infiltration and drain into the ephemeral lake of the Sebkha. Oxidizing conditions persist throughout this zone. The interval from the middle of the hummock ( $c a 1.25 \mathrm{~m}$ ) to $\sim 6 \mathrm{~m}$ depth is also within the unsaturated zone, but is normally a zone of evaporative loss supplied by the underlying aquifer. Infiltration may occur through this zone during exceptional rains. The zone at depth $\sim 7 \mathrm{~m}$ below the hummock surface is mainly influenced by the supply of reduced groundwater from the Continental Intercalaire. 


\section{Age Comparisons for Cerastoderma}

As mentioned above, the ${ }^{14} \mathrm{C}$ ages of Cerastoderma shells are older than those obtained on micrite from the same horizon. This was attributed to an input of old TDIC from the confined aquifer to the Cerastoderma habitat. This effect is also noticeable on coarse fractions of inorganic carbonates that crystallized in bottom sediments. Although the Cerastoderma shells have very low ${ }^{232} \mathrm{Th}$ contents, indicating the absence of detrital material, their U/Th ages are also too old. This can be explained only by a loss of $U$ from their aragonite, which is probably a consequence of their hydrological setting. The shells are present as high-porosity lumachelle layers in the upper part of the hummock, and have been exposed to oxidizing meteoric water, which has partially dissolved their $\mathrm{U}$ content.

\section{Uranium Loss From Cerastoderma Shells}

The evident uranium loss from the aragonite of Cerastoderma shells is in contrast with its conservation in the inorganic calcite. We have estimated the amount of $U$ that has been leached from the shells to make their U/Th ages and the ${ }^{14} \mathrm{C}$ ages of the micrite concordant. We assume that $\mathrm{U}$ removal occurred without isotopic fractionation so that the $\left({ }^{234} \mathrm{U} /{ }^{238} \mathrm{U}\right) \mathrm{AR}$ remained constant, which is justified by the constancy of this ratio in the profile (Table 1). In the short time that has elapsed since sediment deposition, this ratio would not have declined by more than $4 \%$ of its initial value. Table 2 gives the results of these calculations for the alternative assumptions: 1 ) that the $U$ loss was very recent; 2 ) that the loss occurred in a single stage some time after the beginning of the arid period, perhaps $2 \mathrm{ka}$ ago, when eolian deflation had already excavated the sediment.

The insoluble nature of Th ensures that ${ }^{230} \mathrm{Th}$ is immobile in groundwater and, hence, is conserved in the solid phase. The decrease of $U$ content increases the $\left({ }^{230} \mathrm{Th} /{ }^{234} \mathrm{U}\right) \mathrm{AR}$ in reciprocal proportion to the $U$ loss. In the case of recent loss of $U$ (over the last few centuries), the initial $U$ content would have been 1.93 and $1.07 \mathrm{ppm}$ for samples $87 / 338 \mathrm{C}$ and $87 / 331 \mathrm{C}$, respectively. These initial values are comparable with those reported for mollusk shells in continental environments (Kaufman 1971; Gaven, Hillaire-Marcel \& Petit-Maire 1981; Causse et al. 1989). If the U loss occurred at

TABLE 2. The effect of assumed $\mathrm{U}$ loss on the ${ }^{230} \mathrm{Th} /{ }^{234} \mathrm{U}$ age of cardium (Cerastoderma) shells from Sebkha Mellala, Algeria

\begin{tabular}{lcccc}
\hline $\begin{array}{l}\text { Assumed } \\
\text { U loss }(\%)\end{array}$ & $\begin{array}{c}\text { Initial } \mathrm{U} \\
(\mathrm{ppm})\end{array}$ & $\begin{array}{r}{ }^{234} \mathrm{U} /{ }^{238} \mathrm{U} \\
\text { activity }\end{array}$ & $\begin{array}{c}{ }^{230} \mathrm{Th} /{ }^{234} \mathrm{U} \\
\text { ratios }\end{array}$ & $\begin{array}{c}\text { Age } \\
(\mathrm{ka})\end{array}$ \\
\hline Sample 87/338 & & & & \\
0 & 1.07 & 1.56 & 0.117 & 13.4 \\
20 & 1.34 & 1.56 & 0.094 & 10.7 \\
40 & 1.78 & 1.56 & 0.070 & 7.9 \\
$45^{*}$ & 1.93 & 1.56 & 0.064 & 7.2 \\
$60^{* *}$ & 2.68 & $1.57^{\dagger}$ & $0.047^{\dagger}$ & 7.2 \\
Sample 87/331 & & & & \\
0 & 0.80 & 1.42 & 0.093 & 10.6 \\
20 & 1.00 & 1.42 & 0.074 & 8.4 \\
$25^{*}$ & 1.07 & 1.42 & 0.070 & 7.9 \\
$43^{* *}$ & 1.40 & $1.43^{\dagger}$ & $0.053^{\dagger}$ & 7.9 \\
\hline
\end{tabular}

*Recent $\mathrm{U}$ loss for which $\mathrm{Th} / \mathrm{U}$ and ${ }^{14} \mathrm{C}$ ages of micrite are concordant ** Concordance with ${ }^{14} \mathrm{C}$ age for a discrete $\mathrm{U}$ loss $2 \mathrm{ka}$ ago

${ }^{+234} \mathrm{U} /{ }^{238} \mathrm{U}$ and ${ }^{230} \mathrm{Th} /{ }^{234} \mathrm{U}$ activity ratios at $2 \mathrm{ka}$ 
$2 \mathrm{ka}$ ago, the initial $\mathrm{U}$ content would have been significantly higher, 2.68 and $1.40 \mathrm{ppm}$ for $87 / 338 \mathrm{C}$ and $87 / 331 \mathrm{C}$, respectively. As the Sebkha environment is rich in $U$, it is probable that the latter hypothesis is more representative. This would mean that the erosive evolution of the lacustrine deposits took place soon after the beginning of the Saharan desiccation, about 4 ka ago (Gasse et al. 1990). The water table must have declined contemporaneously with the eolian erosion of the Sebkha surface.

\section{Comparison of ${ }^{14} \mathrm{C}$ and $\mathrm{U} / \mathrm{Th}$ Ages for the Micrite}

The agreement between corrected U/Th and ${ }^{14} \mathrm{C}$ ages of the sediments from the upper part of the profile is a priori surprising because it shows that there has been little $U$ mobilization. An explanation for the immobility of $U$ in the upper sediment (10-13 ppm in the upper $1.25 \mathrm{~m})$ lies in the high content of well-preserved organic matter with low $\mathrm{C} / \mathrm{N}$ weight ratios (Gibert, Monrozier \& Fontes, in preparation). Hence, the fine-grained fraction of the lacustrine sediment is still highly reducing and, as the reduced form of $U$ is immobile in aqueous systems, has retained most its $U$ content.

The low U/Th ages (compared with ${ }^{14} \mathrm{C}$ ages) for samples below the inundation level of the Sebkha $(2.80,4.70$ and $6.10 \mathrm{~m})$ but above the water table, imply a gain of $U$. This is consistent with their hydrological situation, $U$ being leached from the hummock and the basin margins by the sporadic heavy precipitation that typifies arid climates. On subsequent infiltration, $U$ is trapped in the more reducing conditions of the sub-Sebkha surface. Thus, $U$ is now being transported downwards and is accumulating at levels that still retain reducing conditions, as shown by samples at depths 2.80 , 4.70 and $6.10 \mathrm{~m}$ (though perplexingly not at $3.90 \mathrm{~m}$ ). Similar conditions probably existed for samples at 1.50, 2.05 and $2.35 \mathrm{~m}$ during the deflation of the Sebkha surface (post $5 \mathrm{ka} \mathrm{BP}$ ), and both have U/Th ages that are too young because of the uranium that was trapped during earlier episodes of Sebkha flooding.

The agreement between the ${ }^{14} \mathrm{C}$ and $\mathrm{U} / \mathrm{Th}$ whole sample ages (87/297 and 87/300) at the bottom of the profile shows that the U/Th system has remained closed and that the sample is almost entirely authigenic. The absence of detrital material is also indicated by the low content of ${ }^{232} \mathrm{Th}$. Trapping of $U$ has not influenced these samples from close to the water table because they have been protected by the upwards recharge (U-poor, reducing groundwater) from the Continental Intercalaire. The ages (12.8-14 ka) for these samples confirm that all the postglacial evolution is recorded in the Sebkha Mellala sediments.

\section{CONCLUSIONS}

This study demonstrates that $\mathrm{U} / \mathrm{Th}$ ages are subject to distortions caused by $\mathrm{U}$ mobility, and that both U losses and gains occur, even in U-rich continental sediments. A comparison of U/Th with ${ }^{14} \mathrm{C}$ ages provides a tool for investigating the mobility of $\mathrm{U}$ in Late Quaternary deposits, and aids the identification of those $\mathrm{Th} / \mathrm{U}$ ages that represent closed-system conditions.

We have also shown that $U$ is relatively conserved in reducing environments, for example, in sediments with a high content of organic matter or where the redox conditions are controlled by proximity to the saturated zone of a confined aquifer. Where such redox conditions exist in the Sebkha Mellala sediments, the agreement between U/Th and ${ }^{14} \mathrm{C}$ ages is acceptable, and the U/Th data may be used to substantiate the ${ }^{14} \mathrm{C}$ time scale. It is unlikely that a consistent $\mathrm{U} / \mathrm{Th}$ chronology can be obtained through a cross-section of dewatered and oxidized sediments. The method should be more reliable in deep lakes that have maintained reducing and, therefore, closed conditions for $\mathrm{U}$ migration in their sediments. 


\section{ACKNOWLEDGMENTS}

We thank Maurice Arnold for assistance with AMS measurements of ${ }^{14} \mathrm{C}$, Georges Conrad and Françoise Gasse for contribution to the field work. This work is a contribution to the PALHYDAF project (Centre National de la Recherche Scientifique, Institut National des Sciences de l'Univers).

\section{REFERENCES}

Bard, E., Hamelin, B., Fairbanks, R. G. and Zindler, A. 1990 Calibration of the ${ }^{14} \mathrm{C}$ time scale over the past 30,000 years using mass spectrometric U/Th ages from Barbados corals. Nature 345: 405-410.

Bischoff, J. L. and Fitzpatrick, J. A. 1991 U-series dating of impure carbonates: An isochron technique using total-sample dissolution. Geochimica et Cosmochimica Acta 55: 543-554.

Causse, C., Conrad, G., Fontes, J.-Ch., Gasse, F., Gibert, E. and Kassir, A. 1988 Le dernier "Humide" pléistocène du Sahara nord-occidental daterait de 80100,000 ans. Comptes Rendus de l'Académie des Sciences 306, Série II: 1459-1464.

Causse, C., Coque, R., Fontes, J.-Ch., Gasse, F., Gibert, E., Ben Ouezdou, H. and Zouari, K. 1989 Two high levels of continental waters in the southern Tunisian chotts at about 90 and $150 \mathrm{ka}$. Geology 17: 922-925.

Deines, P. 1980 The isotopic composition of reduced organic carbon. In Fritz, P. and Fontes, J.-C., eds., Handbook of Environmental Geochemistry, Vol. 1 "The Terrestrial Environment" A: Elsevier: 329-406.

Fontes, J.-Ch. and Gasse, F. 1991 Palhydaf (Palaeohydrology in Africa) Program: Objectives, methods and major results. Palaeogeography, Palaeoclimatology, Palaeoecology 84: 191-215.

Gasse, F., Fontes, J.-Ch., Plaziat, J. C., Carbonel, P., Kaczmarska, I., de Deckker, P., Soulié-Märsche, I., Callot, Y. and Dupeuble, P. A. 1987 Biological remains, geochemistry and stable isotopes for the reconstruction of environmental and hydrological changes in the Holocene lakes from Northern Sahara. Palaeogeography, Palaeoclimatology, Palaeoecology 60: 1-46.

Gasse, F., Téhet, R., Durand, A., Gibert, E. and Fontes, J.-Ch. 1990 The arid-humid transition in the Sahara and the Sahel during the last deglaciation. Nature 346: 141-146.

Gaven, C., Hillaire-Marcel, C. and Petit-Maire, N. 1981 A Pleistocene lacustrine episode in southeastern Libya. Nature 290: 131-135.

Gibert, E., Arnold, M., Conrad, G., de Deckker, P., Fontes, J.-Ch., Gasse, F. and Kassir, A. 1990 Retour des conditions humides au Tardiglaciaire au Sahara septentrional (Sebkha Mellala, Algérie). Bulletin de la Société Géologique de France 8 (VI, 3): 497-504.

Gibert, E., Monrozier, L. and Fontes, J.-Ch. (ms.) Nitrogenous component and organic matter of paleo- sediments from Northern Sahara. Incidence on $\delta^{13} \mathrm{C}$ of associated carbonates. In preparation.

Hillaire-Marcel, C. and Casanova, J. 1987 Isotopic paleohydrology of the Magadi (Kenya) Natron (Tanzania) basin during the Late Quaternary. Palaeogeography, Palaeoclimatology, Palaeoecology 58: 155-181.

Kaufman, A. 1971 U-series dating of Dead Sea Basin carbonates. Geochimica et Cosmochimica Acta 35: 1269-1281.

Kaufman, A. and Broecker, W. 1965 Comparison of ${ }^{230} \mathrm{Th}$ and ${ }^{14} \mathrm{C}$ ages for carbonate materials from Lakes Lahontan and Bonneville. Journal of Geophysical Research 70: 4039-4054.

$\mathrm{Ku}, \mathrm{T}$. L. and Liang, Z. C. 1984 The dating of impure carbonates with decay-series isotopes. Nuclear Instruments and Methods 223: 563-571.

Luo, S. and Ku, T. L. $1991 \mathrm{U}$-series isochron dating: A generalized method employing total-sample dissolution. Geochimica et Cosmochimica Acta 55: 555564.

Przybylowicz, W., Schwarcz, H. P. and Latham, A. G. 1991 Dirty calcites 2. Uranium series dating of artificial calcite-detritus mixtures. Chemical Geology (Isotope Science section) 86: 161-178.

Rosholt, J. N. $1976{ }^{230} \mathrm{Th} /{ }^{234} \mathrm{U}$ dating of travertine and caliche rinds. Geological Society of America, Abstracts with Programs 8: 1076.

Rozanski, K., Goslar, T., Dulinski, M., Kuc, T., Pazdur, M. F. and Walanus, A. 1992 The Late GlacialHolocene transition in Central Europe derived from isotope studies of laminated sediments from the Lake Gosciaz (Central Poland). In Bard, E. and Broecker, W. S., eds., The Last Deglaciation: Absolute and Radiocarbon Chronology. NATO ASI Series I 2. Berlin/Heidelberg, Springer-Verlag: 69-80.

Schwarcz, H. P. and Latham, A. G. 1989 Dirty calcites. Uranium-series dating of contaminated calcite using leachates alone. Chemical Geology 80: 35-43.

Talbot, M. R. and Kelts, K. 1986 Primary and diagenetic carbonates in the anoxic sediments of Lake Bosumtwi, Ghana. Geology 14: 912-916.

Zouari, K. 1987 Géochimie et sédimentologie des dépôts continentaux d'origine aquatique du Quaternaire supérieur du Sud Tunisien: Interprétations paléohydrologiques et paléoclimatiques. Ph.D. Thesis, Université Paris XI: 216 p. 